\title{
A New Industrial Policy for the Italian Start-Up Ecosystem*
}

\author{
Roberto Volpe $e^{* *}$, Mattia Corbetta ${ }^{* * *}$
}

\begin{abstract}
Since 2012 the Italian Government has been engaged in the creation of a farreaching legislative package aimed at supporting the development of the national start-up ecosystem. Drawing from policy suggestions by key players of the Italian innovation ecosystem, the so-called Italian Startup Act encompasses a vast and diversified array of tools affecting all stages of the lifecycle of newly established high-tech businesses. Data regarding the impact of the policy are publicly accessible and are subject to continuous reporting, culminating in the issuance of the Annual Relation to the Italian Parliament by the Italian Minister of Economic Development.
\end{abstract}

Keywords: Start-up; Ecosystem; Innovation; Competitiveness; Open Data; Evidence-Based Policy Making; Global Markets; Global Competition

\section{A New Industrial Policy for the Italian Start-up Ecosystem: Vision and Legislative Process}

The Italian Government has worked since 2012 on the definition of a comprehensive legislation aimed at the development of a vital ecosystem of technologically-intensive innovative start-ups. The first major stepping stone of this work is the Decree-Law 179/2012 on "Further urgent measures for Italy's economic growth", also known as "Growth Decree 2.0" (Decreto Crescita 2.0).

Law 221/2012 includes many of the policy proposals put forward in the Restart, Italia! Report - a report elaborated by a task force of 12 experts, set up in April 2012 by the Minister of Economic Development - as well as crowdsourced suggestions from many players in the Italian start-up ecosystem. With this law, the concept of innovative start-up, meaning a new innovative enterprise of a high technological value, has been introduced into the Italian legal system. For the very first time, this type of enterprise can benefit an extensive corpus of regulations (articles 25-32) that launched new instruments and support measures regarding

\footnotetext{
* Invited Article

** Members of DG for Industrial Policy, Competitiveness and SMEs (roberto.volpe.ext@mise.gov.it) *** Competitiveness and SMEs, Italian Ministry of Economic Development (mattia.corbetta@mise.gov.it)
} 
subjects which have an impact on the whole lifecycle of a company: foundation, growth, development and maturity stages.

Far from being static, the policy for innovative start-ups is in constant evolution, More recent legislative measures (Decree-Law 76/2013, known as "Decree on Labour"; Decree-Law 3/2015, known as "Investment Compact"), have improved and widened the range of measures in favour of innovative start-ups. The measures described in this article will take in account all the most recent developments.

\section{Definition, Data Exposure and Public Monitoring}

An innovative start-up is not any kind of newly-established company. The law awards this facilitating regime only to the companies that show a clear element of technological innovation. However, this phrase does not refer only to enterprises operating in sectors such as information technology: "technological innovation" is taken as an extensive concept applicable to all economic sectors, which may also cover traditional sectors such as manufacturing, handicraft or agriculture.

An innovative start-up is a company with shared capital (i.e. limited companies), or a cooperative, whose capital shares are neither listed on a regulated market nor on a multilateral negotiation system, and which meets the following requirements:

$\checkmark \quad$ is new, or has been operational for less than 5 years;

$\checkmark \quad$ has their headquarters in Italy or in another EU country, as long as it has a production site in Italy;

$\checkmark \quad$ has a yearly turnover lower than 5 million Euros;

$\checkmark \quad$ does not distribute profits;

$\checkmark \quad$ produces, develops and commercialises innovative goods or services with a high technological value;

$\checkmark \quad$ is not the result of a merger, split-up or selling-off of a company or branch;

$\checkmark \quad$ has an innovative character, which can be identified by at least one of the following criteria:

1. at least $15 \%$ of company expenses can be attributed to R\&D activities;

2. at least $1 / 3$ of the total workforce are $\mathrm{PhD}$ students, $\mathrm{PhD}$ graduates or researchers; alternatively, 2/3 of the total workforce must hold a Master's degree;

3. the enterprise is the holder, depositary or licensee of a registered patent (industrial property) or the owner of a program for original registered computers.

The special regime is applicable for a maximum of 5 years, starting from the date of incorporation of the company, which may not be the same of their official recognition as an innovative start-up.

\subsection{How to Enter the Public Directory for Innovative Start-ups}

Indeed, to access the innovative start-up status, the company must be registered the special section of the Register of Companies created ad hoc at the Chambers of Commerce. Registration occurs by transmitting online a declaration of selfcertification, in which the start-up declares to fulfil all the requirements indicated above. 
This flexible entry mechanism is balanced by two counterweights: ex post supervision by the police authorities on the actual fulfilment of all required qualifications, and a duty to update twice a year (deadlines on 30 June and 31 December) the data provided at time of registration, and to confirm once a year the fulfilment of the requirements. In case of failure to comply this obligation or loss of the requirements, the special status and the right to the connected benefits is lost.

The innovative start-up register is publicly available in electronic format, updated every week by the Chambers' system, in order to give publicity, foster widespread monitoring and spur a healthy debate on the impact of the new legislation on economic growth, employment and innovation.

To empower and further develop the information capital enshrined in the special section of the Business Register, on 13 November 2015 a new online platform, \#ItalyFrontiers (http://start-up.registroimprese.it/isin/home), has been established.

On this new platform, every registered start-up has a public profile, both in an Italian and English language version, which by default includes the details already available in the Business Register (corporate purpose, location, main sectoral area and operational activities, number of employees, capitalization, production worth). However, the company can customise its profile much more in detail, providing more in-depth information about the stage of development of the business, the characteristics of the team members, the type of products or services offered, its funding needs, financing received and target markets. Once the legal representative of the firm has validated the details provided, through a fully online procedure, the data are available to everyone visiting the public profile of the business.

As a whole, the profiles are intended to act as a digital showcase for innovative start-ups: they may be read by more traditional firms interested in setting up partnerships, and by national and international investors looking for new opportunities.

\subsection{Monitoring and Evaluation}

in order to fulfil the goal of setting up an "evidence-based policy", the corpus of regulations on start-ups provides for a comprehensive monitoring and evaluation system. In addition, the Minister of Economic Development must report to the Italian Parliament annually on the impact of the measures in question. On 1 March 2014, the Minister of Economic Development discussed the first "Annual Report to the Parliament on the Start-up Law". The Report collected the results of the analysis carried out by the Monitoring and Evaluation Committee (set up by Ministerial Decree approved on 31 January 2014). The second Annual Report has been published on 16 December 2015, also available in English.

The Ministry of Economic Development carries out a comprehensive reporting effort, in order to monitor the evidences of the effects of the policy on innovative start-ups and to share them with the public. All the reports are available to everyone on the Ministry's website. 


\section{Benefits}

The measures described below apply to innovative start-ups since their registration to the special section of the Business register, and for a maximum of 5 years from their incorporation. As they cover all stages of the lifecycle of the business (birth, growth, maturity), they are presented here in a sequential, logical order.

\subsection{Incorporation and Following Statutory Modifications by Means of a Standard Model with Digital Signature}

Innovative start-ups and certified incubators will be able to draw up the deed of incorporation and its subsequent modifications using a typified standard model and digital signature ('firma digitale'), analogously to what is already in place for enterprise networks ('reti d'impresa'). The deed of incorporation and its modifications are drawn up according to a uniform model, which will be adopted by Ministerial decree, and are transmitted to the competent office of the Registry of Companies. The new procedure will be fully operational in mid-2016.

Cuts to red tape and fees: unlike most companies, innovative start-ups are exempted from the payment of stamp duty and fees incurred due to the obligation of registering to the company register, as well as the payment of the annual fee due to the Chambers of Commerce. The exemption from such fees can be interpreted as a general waiver, covering all the actions carried out by the innovative start-ups after the subscription to the company register, such as incentivised capital increases.

Flexible corporate management: the most significant waivers are provided for in the case of innovative start-ups incorporated as S.r.l. (the equivalent of an Ltd.), for which the following are permitted:

a. creation of categories of shares with specific rights (for example, categories of shares that to not attribute right to vote or that attribute such rights in nonproportional terms to the participation);

b. the possibility of carrying out operations on one's shares;

c. the possibility of issuing participative financial instruments;

d. public offer of capital shares.

Many of these measures imply a radical change in the financial structure of the S.r.l, approaching that of an S.p.a. (the equivalent of an Inc.).

Exemption from the regulations on companies reporting systematic losses: during their first few years of activity, innovative, high-risk companies may record losses. If the available capital is insufficient, such losses may have a direct impact on the company's share capital. Where losses result in the share capital being reduced by over $1 / 3$, the shareholders' meeting must lower the capital proportionally to the losses recorded by the following financial year. A 12-month extension is applied to innovative start-ups, during which the capital can be reduced proportionally to the losses. While ordinary companies must lower capital by the following financial year, start-ups can do this for up to two financial years after they suffered losses.

Exemption from regulations on dummy companies: regulations concerning 
non-operational dummy companies which constantly make a loss, do not apply to start-ups. Accordingly, in case they cannot get "appropriate" revenues, they are exempted from fiscal penalties applied to so-called "dummy companies", such as the computation of a minimum income and taxable base for corporate taxation purpose (IRAP).

Exemption from the duty to affix the compliance visa for compensation of VAT credit: the ordinary norm calling for the application of the compliance visa for compensation in F24 of VAT credits above 15,000 euros, may constitute a disincentive to the use of horizontal compensation. With the exemption up to 50,000 euros, innovative start-ups may receive relevant benefits in terms of liquidity during the delicate phase of investment in innovation.

Tailor-made labour law: innovative start-ups must comply, with some exceptions, with the regulations on fixed-term contracts as defined in Decree-Law 81/2015 (known as 'Jobs Act'). Therefore, innovative start-ups can hire a staffer on a fixed-term contract for a maximum length of 36 months. However, in this time frame, in derogation to Jobs Act's provisions, innovative start-ups can hire personnel through fixed-term contracts of any duration, even very short, which can be renewed as many times as wished. After 36 months, the contract can be renewed only once, for a 12 months maximum, leading to overall employment duration of 48 months. By the end of this 4-year period, usually marked by high enterprise risk, the fixed-term contract is automatically converted into an open-ended one. Moreover, as an exception to general regulation, innovative start-ups with more than 5 employees are not required to maintain a statutory ratio between fixed-term and active open-ended contracts.

Flexible remuneration system: the salaries of the employees in innovative startups can have a variable component linked to efficiency or profitability of the company, the productivity of the employee or the team of employees, or to other objectives and parameters for output and performance as agreed upon by the parties, including what is listed below.

Remuneration through stock options and work for equity schemes: in order to foster loyalty among management, employees and suppliers such as lawyers and accountants, start-ups and incubators may offer them capital shares by way of additional remuneration. The revenues resulting from these financial instruments are tax deductible for both fiscal and contributory purposes. In other words, innovative start-ups and certified incubators may make use of instruments such as stock options and work for equity schemes on even better terms than big companies listed on the Stock Exchange.

Tax incentives for corporate and private investments in start-ups made by individuals (19\% tax credit up to a maximum investment of $500,000 €$ ) or legal entities (20\% fiscal deduction up to a maximum investment of 1.8 million $€$ ) for the years 2013, 2014, 2015 and 2016. These incentives apply both in case of direct investments in start-ups and in case of indirect investments by means of other companies investing predominantly in start-ups. Tax benefits are greater if the investment concerns start-ups with a social goal or those operating in the energy sector (25\% tax credit for people or $27 \%$ fiscal deduction for legal entities).

Possibility to collect capital through authorised equity crowdfunding portals. In July 2013, Italy was the first country in the world to enact comprehensive 
regulation for this instrument. In early 2015, the already mentioned Decree-Law 'Investment Compact' has introduced three important amendments:

e. innovative SMEs can now take advantage of the instrument;

f. CIUs and other corporations that invest predominantly in innovative startups and SMEs can use equity crowdfunding as well, an evolution that allows for the diversification of the portfolio and decreased risk towards retail investors

g. once again waiving ordinary norms, the transfer of shares of innovative start-ups and SMEs is dematerialised, and as such related burdens are reduced, aiming for fluidification of the secondary market.

By an impending deliberation, CONSOB, the equivalent of the American SEC ${ }^{\dagger}$, will update the Regulation, adding to the aforementioned measures new procedural simplifications. The verification of adequacy of the investment will be carried out by the administrators of the portals themselves, and not exclusively by banks as required before, bringing the entire procedure online. Moreover, two new categories of professional investors will be added: "professional investors on request', identified according the EU directive 'Markets in Financial Services' (Mifid), and "investors in support of innovation', which includes actors such as business angels.

Fast-track, simplified and free-of-charge access for innovative start-ups and certified incubators to the Fondo di Garanzia per le Piccole e Medie Imprese, a Government Fund that supports access to credit through guarantees on bank loans (Implementing Decree). The guarantees covers $80 \%$ of the bank loans up to a maximum of 2.5 million $€$, and it is provided through a simplified fast-track procedure.

More targeted support to the process of internationalisation provided by the Italian Trade Agency ('ICE', dedicated website), including assistance in legal, corporate and fiscal activities, as well as real estate and credit matters. In addition, innovative start-ups can benefit from free-of-charge participation to selected international fairs and events, as well as to international initiatives aimed at favouring the matching with potential investors. A 'Start-up service card' has been released by the Agency, granting 30\% reductions on its assistance services.

'Fail fast' procedure: the aim of this measure is to avoid that the entrepreneur is 'stuck' for ages because of the liquidation procedure and allow him to start a new business project as soon as possible without suffering reputational and financial cost. More in detail, start-ups are exempted from the standard bankruptcy procedure, preliminary closure agreements and forced liquidation in the event of an over-indebtment crisis. As a result, waiting times are cut, and the administrative and reputational burden sharply reduced.

For any question on the functioning and the interpretation of those norms, anyone interested can write to the email address start-up@mise.gov.it, which has been operational every day for almost 4 years. 


\section{Additional Support Measures}

Public support measures especially relevant for innovative start-ups are not limited to the original package of regulations. Here are some other programmes in which the Italian Ministry of Economic Development is engaged.

Smart\&Start Italia: The Ministerial Decree enacted on 24 September 2014 introduced a subsidised financing scheme for innovative start-ups based in Italy, regardless their region of operation. Total financing amounts to $€ 200$ million, available until depletion to projects whose spending in investment goods and/or management costs are between $€ 100,000$ and $€ 1.5$ million. The financing scheme will cover such spending programmes through zero-interest mortgages for $70 \%$ of their total amount; the coverage ratio rises to $80 \%$ when a majority of business associates and employees are women or below 35 years of age. Moreover, when the beneficiary is an innovative start-up based in a Southern Italian region (Basilicata, Calabria, Campania, Puglia, Sicilia), a $20 \%$ of the funding is converted into an outright grant. Access to the measure is also open to individuals who are committed to establish a new innovative start-up in the next 60 days. Start-ups which are less than 12 months old can also benefit from a tutoring service for technical and management issues. In addition, a preferential track is provided to innovative startups which commit themselves to finance at least $30 \%$ of their investment plan with capital coming from institutional investors.

Together with the collaboration of the Ministry of Foreign Affairs, the Ministry of Labour and Social Policies and the Ministry of Interior, the Ministry of Economic Development promotes a visa policy dedicated to non EU innovative entrepreneurs, as a strategic way to attract in Italy investment and highly qualified human capital. Launched on 24 June 2014, Italia Start-up Visa (italiastart-upvisa.mise.gov.it) has introduced a swift, completely online, centralised and simplified mechanism for granting working visas to applicants intending to set up a new innovative start-up in our country or join an existing one as a working shareholder.

On 23 December 2014, following the model of Italia Start-up Visa, the Italia Start-up Hub programme was launched. Through this channel, the abovementioned fast-track procedures are extended to extra-EU citizens that are already in possession of a regular residency permit (obtained for example for study reasons) and intend on staying beyond its expiry to launch an innovative start-up: in this way, it is possible to convert a residency permit into a 'permit for entrepreneurs in an innovative start-up' without leaving the Italian territory and benefitting from the same simplified measures provided for the start-up visa. The official website of the programme, italiastart-uphub.mise.gov.it, entirely redacted in English, will be published in April 2016.

\section{Empirical Evidence: Key Figures from the Special Section of the Business Registry and Periodic Reports}

The section of the Business Registry dedicated to innovative start-ups is freely accessible and weekly updated. As a result, it allows a constant, accurate monitoring on the number and some key features of the innovative start-ups that 
benefit from the policy here described.

In the last weekly update concerning 2015 data there were 5,415 companies registered in the special section of the Business Registry.

The Region with the highest number of registered start-ups is Lombardy $(1,126)$, followed by Emilia-Romagna (579), Lazio (502), Veneto (384) and Piedmont (356). The top 5 provinces are Milan (759), Rome (434), Turin (267), Naples (165) and Bologna (148). A majority of companies is based in the North of the country (55.4\%), with the rest roughly equally divided between the Centre $(21.8 \%)$ and the South $(22.8 \%)$.

According to legal status, a vast majority of start-ups are regular S.r.l companies $(4,088)$; other 732 are simplified S.r.l.'s (S.r.l.s.). 106 are cooperatives and only 67 are S.p.a.'s (regular joint stock companies).

1,615 start-ups were incorporated in 2015 and 1,546 in 2014, a 4.5 percent increase year on year. As far as it concerns years that fully predated the entry into force of the policy, 513 were incorporated in 2012, 307 in 2011, 162 in 2010.

Sectoral distribution is largely dominated by services $(3,889)$, which include software production $(1,538)$, scientific research and development (795), and other IT services (418). 952 start-ups operates in industry and manufacturing, 231 in trade, 38 in tourism and 15 in agriculture.

For production value, which can be calculated only on start-ups that already presented at least one statement of accounts $(2,494)$, it is possible to evidence that for a vast majority of them this value is below $€ 100,000$ (1,703). 736 are above this threshold but below $€ 1 \mathrm{M}$, while 54 are so-called 'millionaire start-ups'. It is important to note that, by definition, no registered innovative start-up can possibly have a production value higher than $€ 5 \mathrm{M}$. Through social security data (only available for 2,098 start-ups), we know that 1,779 have less than 4 employees (including those that have zero), 232 between 5 and 9, 68 between 10 and 19, 19 more than 20 employees.

3,337 companies declare to spend in $R \& D$ activities a sum amounting to more than $15 \%$ of their costs or production value, thus fulfilling the first innovation requirement. 1,528 comply with the requirements on highly-qualified workforce, 1,010 with that for registered software. Many start-ups are in possession of at least two of these requirements, and 136 declare all of the above.

Some other elements can be obtained from the three-monthly report on the trends in the special section of the Registry. From the edition published on 31 December 2015, we know that on that day innovative start-ups represented $0.33 \%$ of all limited companies in the country. Their overall share capital is just above 258 million euros, corresponding to an average of almost 50,000 euros per company.

The three-monthly report allows to put into a broader context the data on sectoral distribution. $22.5 \%$ of limited companies that carry out $R \& D$ activities as their primary goal are innovative start-ups; a significant percentage of software production companies are too $(6.3 \%)$.

The report also includes data on female and youth employment, unavailable on the weekly updates. On late December, 678 innovative start-ups were exclusively or prominently composed of women: $13.2 \%$ of all start-ups, while for all shared capital companies this percentage is higher, at $16.6 \%$. Women are underrepresented also when looking at companies with at least one female shareholder $(44.3 \%$, 
against $50 \%$ for all companies).

On the other hand, young people are indeed overrepresented: $24 \%$ of all start-up have a majority of associates below 35 years of age, a value almost three and a half times higher than that registered in regular limited companies.

In addition, there are 112 registered companies (2.2\%) whose shareholders are mostly or exclusively non-Italian citizens. Overall, the percentage of innovative start-ups with at least a foreigner in their property structure is higher than that registered for all shared capital companies (12.2\% against $10.3 \%)$.

An interesting feature emerging from this report is the status of the people involved in the start-up. From social security (INPS) data, last recorded on 31 December 2015, it is known that the employees in innovative start-ups are 5,351; the innovative start-ups with at least one employee are 1,939, of which more than half have less than 2 employees.

However, when looking at shareholders, the figure is much different: they are 19,957, approximately 4 per start-up on average: they thus outnumber formal employees almost four times.

Analysing the last statement of account available for reporting purposes (2014), it is possible to evidence that $56.7 \%$ of start-ups registered a loss in that year, dragging down profitability indicators (ROI, ROE) for the whole group. However, when only looking at start-ups $(43.3 \%)$ that registered a profit, those indicators improve vastly, sensibly outperforming regular shared capital companies. On average, all innovative start-ups generate 15 cents of added value per $1 €$, below average; when singling out profitable start-ups, their added value is 34 cents per $1 €$ of production, against 21 cents for all other companies.

A dedicated report, issued every two months, is released for a high-impact instrument: the access to the Public Guarantee Fund for SMEs, which is enjoyed by innovative start-ups through a simplified, fast-track and free-of-charge path. On 31 December 2015, 711 start-ups had applied for bank financing with an intervention of the Guarantee Fund, in 1,054 operations (with some start-ups applying for more than one loan), for an amount of 289,185,329 euros (of which 225.827.047 are guaranteed by the Fund): on average, 274,369 euros per loan. Funding is awarded, on average, for 55 months.

\section{Conclusion}

As the abovementioned figures show, the impact of this policy is becoming more and more substantial. Over 25,000 people are involved in an innovative start-up, either as shareholders or as employees, and the number of applications for the Public Guarantee Fund is becoming very significant in difficult times for SMEs when it comes to credit availability. All trends are increasing and accelerating, showing that the Italian start-up ecosystem is still in an expansionary phase and perspectives for future growth keep being positive.

The Italian Start-up Act is slowly gaining recognition outside the national borders and Italy, according to the European Digital forum, gained the second position in Europe, after the Netherlands, in implementing the 22 policy recommendation of 
the 2013 Start-up Manifesto, a roadmap aiming to improve the performances of the Italian start-up ecosystem.

This shows that the Italian legislative framework is indeed advanced in a European context: Italy has a strategy, a wide-ranging set of policy measures, a well-developed system of monitoring and a strong commitment to effective and deep policy evaluation. In times when the European legislator seems to find it difficult to steer the industrial policy of the Union towards an innovation-oriented direction, the Italian practical experience can be of great use.

\section{Bibliography}

Leaders Club. A manifesto for entrepreneurship and innovation to power growth in the EU. September $2013 . \quad$ Available http://ec.europa.eu/newsroom/dae/document.cfm?action=display\&doc_id=2658.

Commissione Nazionale per la Società e la Borsa (CONSOB). "Regolamento sulla raccolta di capitali di rischio tramite portali on-line", delibera n. 18592, 26/6/2013.

Italian Chambers of Commerce. Report con dati strutturali $-4^{\circ}$ trimestre 2015 - start-up innovative, 31/12/2015, available at http://startup.registroimprese.it/report/4_trimestre_2015.pdf.

Italian Chambers of Commerce. Sezione speciale del registro delle imprese "startup-innovative", start-up.registroimprese.it,

Italian Government. Decreto-Legge 179/2012: "Ulteriori misure urgenti per la crescita del Paese", artt. 25-32, 2012.

Italian Government. Decreto-Legge 76/2013, "Primi interventi urgenti per la promozione dell'occupazione, in particolare giovanile, della coesione sociale, nonché in materia di imposta sul valore aggiunto (IVA) e altre misure finanziarie urgenti" 2013.

Italian Government. Decreto-Legge 3/2015, Misure urgenti per il sistema bancario e gli investimenti, 2015.

Italian Ministry of Economic Development. "Restart, Italia! Perché dobbiamo ripartire dai giovani, dall'innovazione, dalla nuova impresa," September 13, 2012.

http://www.mise.gov.it/images/stories/documenti/start-up_low_small.pdf.

Italian Ministry of Economic Development and Italian Ministry of Finance. Decreto Ministeriale 26/03/2013.

Italian Ministry of Economic Development. Decreto Ministeriale 31/01/2014.

Italian Ministry of Economic Development. "Report to the Parliament on the implementation of regulations in support of the innovative start-up ecosystem", 1 March 2014. Available at: http://www.mise.gov.it/images/stories/normativa/Annual-Report-to-the-Italian-Parliament-on-theStart-up-Law.pdf.

Italian Ministry of Economic Development. "Report to Parliament on the implementation of policies in support of innovative start-ups and SMEs", September 2015.

Italian Ministry of Economic Development. Sintesi dei dati sull'accesso al credito da parte delle start-up innovative e degli incubatori certificati mediante l'intervento del Fondo di Garanzia per le PMI, 7th two-monthly edition, 31/12/2015. Available at: http://www.mise.gov.it/images/stories/documenti/Dati_startup_incubatori_FGPMI_5_ed_31_dicembre_2015.pdf

Italian Ministry of Economic Development. "Start-up Innovative - relazione annuale e rapporti periodici." mise.gov.it. http://www.mise.gov.it/index.php/it/impresa/competitivita-e-nuoveimprese/start-up-innovative/relazione-annuale-e-rapporti-periodici.

Italian Ministry of Economic Development and Italian Ministry of Foreign Affairs. "Italia Start-up Visa - the Italian Government's policy for attracting innovative foreign entrepreneurs - 
Guidelines”, $\quad$ italiastart-upvisa.gov.it, available at: http://italiastartupvisa.mise.gov.it/media/documents/linee_guida_ISV.pdf.

Arora, A., \& Gambardella, A. (2010). The market for technology. Handbook of the Economics of Innovation, 1, 641-678.

http://dx.doi.org/10.1016/S0169-7218(10)01015-4

Arrigo, E. (2012). Alliances, Open Innovation and Outside-in Management, Symphonya. Emerging Issues in Management (symphonya.unimib.it), 2, 53-65

http://dx.doi.org/10.4468/2012.2.05arrigo

Blank, S. (2013). Why the lean start-up changes everything. Harvard business review, 91(5), 63-72.

Bellini, N. (2015). Smart Specialisation in Europe: Looking Beyond Regional Borders, Symphonya. Emerging Issues in Management (symphonya.unimib.it), 1, 22-29 http://dx.doi.org/10.4468/2015.1.03bellini

Brondoni, S.M. (2012). Innovation and Imitation: Corporate Strategies for Global Competition, Symphonya. Emerging Issues in Management (symphonya.unimib.it), 1, 10-24 http://dx.doi.org/10.4468/2012.1.02brondoni

Brondoni, S.M. (2013). Innovation and Imitation for Global Competitive Strategies. The Corporation Development Models of US, Japan, Korea, and Taiwan, Symphonya. Emerging Issues in Management (symphonya.unimib.it), 1, 12-27 http://dx.doi.org/10.4468/2013.1.02brondoni

Risso, M. (2012). Exploring Partnerships for Social Innovation, Symphonya. Emerging Issues in Management (symphonya.unimib.it), 2, 26-36 http://dx.doi.org/10.4468/2012.2.03risso

ROMáN, C., Congregado, E., \& Millán, J. M. (2013). Start-up incentives: entrepreneurship policy or active labour market programme?. Journal of Business Venturing, 28(1), 151-175.

Wade, R. H. (2012). Return of industrial policy?. International review of applied economics, 26(2), 223-239. 